\title{
POLYARTHRITIS AS THE INITIAL MANIFESTATION OF RENAL OSTEODYSTROPHY: CASE REPORT
}

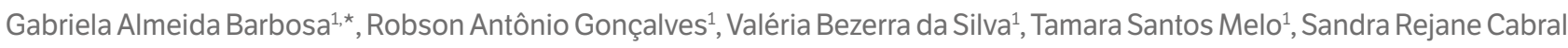
Batista ${ }^{1}$, Maria Roberta Melo Pereira Soares ${ }^{1}$, Ana Karla Guedes de Melo $^{1}$, Danielle Christinne Soares Egypto ${ }^{1}$, Alessandra de Sousa Braz ${ }^{1}$, Eutilia Andrade Medeiros freire ${ }^{1}$
\end{abstract}

1.Universidade Federal da Paraíba, João Pessoa (PB), Brazil.

*Corresponding author: gabrielaalmeidamed@gmail.com

\section{BACKGROUND}

Abnormalities involving the musculoskeletal system are frequent in patients with chronic renal failure (CRF). The most common manifestations are called as renal osteodystrophy (ROD): secondary hyperparathyroidism, osteomalacia and soft tissue and vascular calcification. Chronic polyarthritis of small and large joints is an uncommon symptom in ROD, affecting about $3 \%$ of patients, and resembling rheumatoid arthritis (RA).

\section{CASE REPORT}

Male, 64 years old, with diagnosis of dialytic CRF for 13 years, had started additive and progressive polyarthritis, affecting hands, wrists, hips, knees and ankles for 6 months. He evolved, in a period of 4 months, with progressive weight loss of $12 \mathrm{~kg}$, and joint limitation. Laboratory tests showed rheumatoid factor (RF) of $99 \mathrm{IU} / \mathrm{mL}$, ESR $74 \mathrm{~mm}$ 1st hour (up to $20 \mathrm{~mm}$ ) and C-reactive protein $7.8 \mathrm{mg} / \mathrm{L}$ (up to 6). Treatment was started with prednisone $5 \mathrm{mg} /$ day and methotrexate $15 \mathrm{mg} /$ week. The patient was referred for hospital admission due to rapid deterioration of mobility and decline in his general health condition. Laboratory data showed hemoglobin $8.4 \mathrm{~g} / \mathrm{dL}$ (14 to $18 \mathrm{~g} / \mathrm{dL}$ ), creatinine clearance $11 \mathrm{~mL} / \mathrm{kg} / 1.73 \mathrm{~m}, \mathrm{PTH} 2731 \mathrm{pg} / \mathrm{mL}$ (10 to $65 \mathrm{pg} / \mathrm{mL}$ ), phosphorus $4.2 \mathrm{mg} / \mathrm{dL}$ ( 2 to $4.5 \mathrm{mg} / \mathrm{dL}$ ), calcium $8.8 \mathrm{mg} / \mathrm{dL}$ ( 8.8 to $10.4 \mathrm{mg} / \mathrm{dL}$ ), and radiographs revealed osteolytic lesions in affected joints (Figure 1 ). The diagnosis of secondary hyperparathyroidism was established, in face of laboratory findings and suggestive parathyroid scintigraphy. The patient received treatment with cinacalcet, vitamin D supplementation (calcitriol) and opioid analgesics for symptomatic relief. Given the severity of the clinical condition with polyarticular involvement, total parathyroidectomy was performed. After the surgical procedure, the patient evolved with improvement in joint pain.
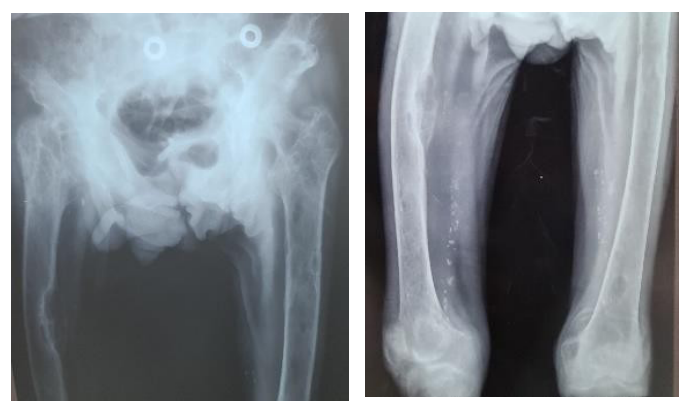

Figure 1. Diffuse osteopenia, bilateral hip joint ankylosis. Presence of osteolytic lesion in the right femur and vascular calcification.

\section{CONCLUSION}

The recognition of musculoskeletal manifestations is important in the clinical management of patients with CRF. Polyarticular involvement and RF positivity can be challenging for the rheumatologist in the management of patients with ROD, requiring high suspicion of differential diagnoses. The management of ROD remains complex and individualized, and require a multidisciplinary approach.

\section{KEYWORDS}

Renal osteodystrophy, Musculoskeletal manifestations, Rheumatoid arthritis. 